\title{
Not-for-profit entrepreneurs
}

\section{Citation}

Glaeser, Edward L. and Andrei Shleifer. 2001. Not-for-profit entrepreneurs. Journal of Public Economics 81: 99-115.

\section{Permanent link}

http://nrs.harvard.edu/urn-3:HUL.InstRepos:33078971

\section{Terms of Use}

This article was downloaded from Harvard University's DASH repository, and is made available under the terms and conditions applicable to Other Posted Material, as set forth at http:// nrs.harvard.edu/urn-3:HUL.InstRepos:dash.current.terms-of-use\#LAA

\section{Share Your Story}

The Harvard community has made this article openly available.

Please share how this access benefits you. Submit a story.

Accessibility 
NOT-FOR-PROFIT ENTREPRENEURS

\author{
Edward L. Glaeser \\ Andrei Shleifer
}

Working Paper 6810

http://www.nber.org/papers/w6810

\author{
NATIONAL BUREAU OF ECONOMIC RESEARCH \\ 1050 Massachusetts Avenue \\ Cambridge, MA 02138 \\ November 1998
}

We are grateful to Gary Becker, David Cutler, Mark Duggan, John Dunlop, Xavier Gabaix, Claudia Goldin, Henry Hansmann, Oliver Hart, Bengt Holmstrom, Larry Katz, Tomas Philipson, Sherwin Rosen, David Scharfstein, Fiona Scott-Morton, Burton Weisbrod, and Daniel Wolfenzon for comments. Financial support was provided by the NSF and the Sloan Foundation. The views expressed here are those of the author and do not reflect those of the National Bureau of Economic Research.

(C) 1998 by Edward L. Glaeser and Andrei Shleifer. All rights reserved. Short sections of text, not to exceed two paragraphs, may be quoted without explicit permission provided that full credit, including (C) notice, is given to the source. 
Not-For-Profit Entrepreneurs

Edward L. Glaeser and Andrei Shleifer

NBER Working Paper No. 6810

November 1998

JEL No. L30, L31

\section{ABSTRACT}

Entrepreneurs who start new firms may choose not-for-profit status as a means of committing to soft incentives. Such incentives protect donors, volunteers, consumers and employees from ex post expropriation of profits by the entrepreneur. We derive conditions under which completely selfinterested entrepreneurs opt for not-for-profit status, despite the fact that this status limits their ability to enjoy the profits of their enterprises. When entrepreneurs have a taste for producing high quality products, the incentives are even softer, and, moreover, non-profit status can serve as a signal of that taste. We also show that even in the absence of tax advantages, unrestricted donations would flow to non-profits rather than for-profit firms because donations have more significant influence on the decisions of the non-profits.

Edward L. Glaeser

Department of Economics

Littauer 315A

Harvard University

Cambridge, MA 02138

and NBER

eglaeser@kuznets.harvard.edu
Andrei Shleifer

Department of Economics

Littauer M9

Harvard University

Cambridge, MA 02138

and NBER

ashleifer@harvard..edu 


\section{Introduction}

In 1966, Robert Brustein founded the Yale Repertory Theater -- a non-profit artistic company with a resident company of actors. The theater's revenues came from Yale University, other funding agencies and ticket buyers. In 1979, Brustein moved his theater to Cambridge (changing its name to the American Repertory Theater) to keep it focused on professional, rather than student, drama. While this theater requires a more permanent commitment (perhaps investment in specific human capital) from its actors than standard theaters do, it is far from being a cooperative. Robert Orchard (managing director of the theater, cited in Ayala and Falstad, 1988) writes "what the company does ultimately reflects his [Brustein's] choices, his tastes, his ideals."

Many, if not most, not-for-profit firms are started by entrepreneurs. In 1864, Jean-Henri Dunant, after witnessing the bloody battle of Solferino, founded the Red Cross. Dunant co-founded another significant non-profit, the World's Young Men's Christian Association, and (after spending most of his life in poverty and obscurity having neglected his business affairs) won the first Nobel Peace Prize in 1901. In 1892, the American John Muir founded the non-profit Sierra Club. In recent years, Michael Brown and Alan Khazei founded City Year, a program dedicated to promoting national service among young people, and Wendy Kopp founded Teach for America, a non-profit service organization attracting recent college graduates to teaching disadvantaged students.

In this paper, we ask a simple question: why would an entrepreneur wish to start a not-forprofit rather than a for-profit firm? We present an answer motivated by the work of Hansmann $(1980,1996)$ and Weisbrod $(1988)^{1}$. Our theory uses the assumption of Hansmann (1996) that "the critical characteristic of a nonprofit firm is that it is barred from distributing any profits it earns to persons who exercise control over the firm." Instead, a nonprofit firm can distribute its profits only

\footnotetext{
${ }^{1}$ Earlier work on non-profit firms includes Arrow (1963) and Nelson and Krashinsky (1973).
} 
through improvements in the working environment of the entrepreneur and the employees, which may include lower effort levels, free meals, shorter workdays, longer vacations, better offices, more generous benefits, or even improvements in the quality of the product ${ }^{2}$. In general, such "perquisites" are not as valuable to an entrepreneur as income, and so it is not obvious why a rational entrepreneur would constrain himself by choosing a non-profit status. The key point is that such status weakens his incentives to maximize profits. This commitment to weaker incentives is valuable in markets where entrepreneurs might be able to take advantage of their customers, employees, or donors, since it reduces their interest in profiting from such opportunities. When customers, employees, or donors feel protected by the non-profit status of the firm, the entrepreneur has a competitive advantage in the marketplace.

We present a model that attempts to capture this idea. Some of the literature on non-profit firms, such as Drucker (1990) and Rose-Ackerman (1996), stresses the altruistic motives of its management. We agree that many founders of non-profit firms are motivated by public spirit and altruism, rather than just profits. At the same time, we believe that one can explain many crucial aspects of non-profit behavior, including which markets they operate in, without relying on the assumption of altruism. Even with the altruism assumption, the question of why an altruistic entrepreneur chooses the non-profit organizational form remains pertinent.

The basic idea of our model is well-known from the theoretical literature on incomplete contracts, including Klein, Crawford, and Alchian (1978), Holmstrom (1982), Grout (1984), Grossman and Hart (1986), and Holmstrom and Milgrom (1991, 1994). In some situations, particularly strong incentives lead to inefficient behavior and cannot be controlled by an explicit

${ }^{2}$ Non-profit firms can also retain their profits for long periods of time. Duggan (1998) shows that Californian non-profit hospitals have saved rather than spent their windfalls from increased transfers from the government. Universities, of course, have retained their income for centuries. 
contract. Such incentives should be moderated by other means. In our context, when high powered incentives resulting from profit maximization can cause entrepreneurs to take actions detrimental to their customers, such as cost reductions that lead to deterioration of quality, commitment to nonprofit status softens these incentives, and thus reassures the customers that entrepreneurs will not take advantage of them ${ }^{3}$. When quality cannot be part of a contract, such a commitment can benefit both the entrepreneur and consumers. Although there are several theoretical ways to make this point, we choose an ex-post expropriation framework that does not rely on asymmetric information between the entrepreneur and consumers ${ }^{4}$.

Many recent discussions of non-profits have focused substantially on their tax advantaged status (Weisbrod 1988, Lakdawalla and Philipson 1998). Our model does not rely on any tax benefits of non-profit firms to explain their existence. While the non-profit status brings significant tax benefits in the United States both for the firms and for the donors, it does not seem to be the essential characteristic of the non-profit firms. First, non-profits such as the Sierra Club were created long before the introduction of the income tax in the United States, and hence are unlikely to be a byproduct of income taxation. Second, and along the same lines, the vast majority of donors to nonprofit firms in the United States are relatively poor individuals who contribute to religious organizations and do not derive tax benefits from their contributions. Third, noncharitable non-profits cannot receive tax-deductible contributions but still exist. Fourth, perhaps the greatest contributions to the non-profits come from the millions of volunteers, who donate non-deductible time rather than

\footnotetext{
${ }^{3}$ Similar issues come up in the discussions of government ownership, see Hart, Shleifer and Vishny (1997) and Shleifer (1998).

${ }^{4}$ Hansmann (1980), whose views we largely share, uses the general label of "contractual failure" to explain the benefits of the not-for-profit status. Hansmann (1996) and Easley and O'Hara (1983) stress more specifically asymmetric information between consumers and entrepreneurs. One way, though not the only way, to interpret the incomplete contracts framework that we rely on is asymmetric information between the trading parties on the one hand and the judge on the other.
} 
the possibly deductible money, and who account for nearly 40 percent of the non-profits' labor input. The tax story thus does not appear to be at the heart of the matter.

Finally, unlike much of the recent literature (Hart and Moore 1997, Kremer 1997), we focus on non-profit entrepreneurs rather than on cooperatives. The cooperatives literature focuses on the consequences of collective decision making. Many non-profits are started by entrepreneurs, and hence do not face this particular problem.

Our basic model examines a firm that sells a commodity to a single consumer. The quality of this commodity has both verifiable (contractible) and non-verifiable components. After the sale, the entrepreneur can exert effort to reduce costs. As in Hart, Shleifer and Vishny (1997), costreducing effort may also reduce the non-verifiable component of consumer quality. Consumers are willing to pay higher initial prices if the firm can commit to making less of such cost-cutting, qualityreducing effort. As a means of such a commitment, non-profit status ensures higher prices. Entrepreneurs choose the non-profit status if the benefits of committing to higher quality outweigh the costs of having to take their net revenues in the form of perquisites rather than cash.

Customers may not be the only ones to prefer dealing with non-profit firms. Employees may invest more in specific human capital at not-for-profit firms because these firms have less financial incentive to cut wages or perquisites ex post. Donors, who may be more important for many nonprofits than customers, almost never have clear contracts specifying their wishes, are better protected against expropriation when they give to non-profits. When customers, employees and donors prefer to contract with not-for-profit entrepreneurs, the latter can get higher utility by committing to notfor-profit status ex ante. This status commits the entrepreneur to softer incentives and higher quality and consequently, in equilibrium, enables him to charge more or get more donations.

The model predicts that non-profit firms play a large role mainly in sectors with opportunities 
for severe ex post expropriation of consumers, employers, or donors. Sectors dominated by nonprofit firms, such as child care, long term care for the aged, the performing arts, hospitals and schools, indeed face such expropriation problems. With child care or schools, parents who pay up front worry that these institutions may hire cheaper but less competent teachers. With the performing arts, performers invest in the theater and the particular performance, and worry about being underpaid or fired. With universities, donors worry that the money be used to create a permanent testimony of their largesse. Weisbrod (1988) discusses the case of long term care for the aged, where for-profit nursing homes evidently used more sedatives (a cheap way to keep patients calm) than the non-profits -- a dramatic example of a cost-reducing strategy adversely affecting non-contractible quality. Hansmann (1996) presents an interesting application of the same idea to saving and loan mutuals in the United States. When these mutuals were founded, the risk of misuse and appropriation of savings of middleclass consumers was significant, and the mutual status was used in part as a commitment to softer incentives $^{5}$.

Although our basic results are driven by the effect of the non-profit status on incentives, and do not rely on entrpreneurial altruism, most founders of non-profits -- such as Dunant or Muir -- have a strong interest in their causes. We show in an extended model that entrepreneurs with a strong taste for quality would opt for non-profit status. When this taste for quality is unobservable, nonprofit status serves as a signal of such taste.

Finally, we examine general (non-targeted) donations from charitable donors who wish to improve product quality. Donations to for-profit firms do not to a first approximation change the

${ }^{5}$ Not-for-profit status is only one of many solutions to expropriation problems; reputationbuilding, certification, and competition are others. Sherwin Rosen asked why the sellers of diamonds do not use not-for-profit status. The quality of diamonds can be, and often is, certified by the Gemological Institute of America. Interestingly, GIA is a non-profit, presumably in part precisely to assure diamond buyers that its incentives to be corrupted by the sellers are weak. 
marginal conditions for production of quality. However, donations to non-profit firms lower the marginal utility of revenues and lead to even softer incentives. Through this channel, unverifiable quality in non-profits may improve. In the same spirit, we examine the role of governing boards of non-profit firms, which are often structured to have very low benefits of perquisites, and also staffed by donors.

In the next section, we present a benchmark model in the spirit of Hart, Shleifer and Vishny (1997), in which firms sell a product to consumers, but may later choose to cut costs and in the process reduce non-contractible quality. This model gives formal conditions under which non-profit firms dominate a market. Section III looks at altruistic entrepreneurs. Section IV discusses the role of non-profits when potential donors seek to increase the quality of products with their donations. Section V concludes.

\section{The Basic Model}

In this section, we consider an entrepreneur's decision of whether or not to obtain non-profit status for his firm as a mechanism of committing to soft incentives. The technological opportunities are identical for all firms. The only difference is that non-profit status limits the ability of the entrepreneur to distribute profits to himself.

At time zero, the entrepreneur decides on non-profit or for-profit status. At time one, the entrepreneur sells exactly one unit of a good to a competitive market of consumers. At the time of sale, the entrepreneur collects the price $\mathrm{P}$ and agrees to deliver at time three a product of verifiable quality $\mathrm{Q}_{1}$. At time two, the firm has an opportunity to make a cost reducing innovation. For an effort cost of $\mathrm{E}$ of discovering and implementing the innovation, the costs of production are reduced by $\mathrm{K}(\mathrm{E})$, where $\mathrm{K}^{\prime}(\mathrm{E})>0, \mathrm{~K}^{\prime \prime}(\mathrm{E})<0, \mathrm{~K}(0)>0$, and $\mathrm{K}^{\prime}(0)=\infty$. The total costs of production are $\mathrm{C}\left(\mathrm{Q}_{1}\right)$ - 
$\mathrm{K}(\mathrm{E})$, where $\mathrm{C}\left(\mathrm{Q}_{1}\right)$ is the basic cost of producing a good of verifiable quality $\mathrm{Q}_{1}$. While verifiable quality $\mathrm{Q}_{1}$ is not influenced by the innovation, and hence the entrepreneur does not violate his agreement with the consumer, total (nonverifiable) quality is reduced to $\mathrm{Q}_{1}-\mathrm{mE}$, where $\mathrm{m}$ is a constant. ${ }^{6}$ In this framework, E and hence the ultimate quality can be perfectly observable to the consumers. The key assumption is that consumers cannot go to a court and complain that the firm has produced shoddy quality, because the court cannot verify the shortfall of quality below the contracted on level. An alternative way to specify this model is by relying on asymmetric information about $\mathrm{E}$ and quality, in the spirit of Hansmann (1996), but it seems to us that in many examples, such as substitution of inferior teachers in schools or use of sedatives in nursing homes, the issue is not customer ignorance but rather contractual incompleteness.

Consumers' utility equals the quality of the good plus net income (gross income minus price of the good). Consumers, then, are willing to pay $q+Q_{1}-m E$ for the good, where $E$ is the anticipated level of unverifiable effort, and $\mathrm{q}$ is a constant. After the entrepreneur chooses $\mathrm{E}$ and $\mathrm{Q}_{1}$, he delivers the good to the consumer at time three.

The total cash profits of the firm are $\mathrm{P}-\mathrm{C}\left(\mathrm{Q}_{1}\right)+\mathrm{K}(\mathrm{E})$. If the firm is for-profit, these profits are realized as income to the entrepreneur. If the firm is not-for-profit, the entrepreneur is forced to spend these revenues on perquisites, denoted by Z. Entrepreneurs maximize a quasi-linear utility function: ${ }^{7}$

$$
\text { Income }+\mathrm{V}(\text { Perquisites })-\text { Effort }=\mathrm{I}+\mathrm{V}(\mathrm{Z})-\mathrm{E} \text {. }
$$

In this section and the next, we further assume that $V(Z)=d Z$, with $d<1$. The entrepreneur would

${ }^{6}$ This innovation could be either socially efficient or not. Some innovations could also raise quality. We only focus on innovations that require effort, and reduce both costs and quality.

${ }^{7}$ At this point, the assumption of linearity in effort represents little loss of generality since the functions mapping effort into cost and cost into quality remain sufficiently general. 
rather have cash than perquisites at the going price for perquisites. Since the entrepreneur could buy many of the perquisites in the open market, receiving compensation in this form is likely to be worse than receiving cash.

We begin with the entrepreneur's decision about his effort level, E. Price P is fixed when the entrepreneur chooses effort. Total utility of a for-profit entrepreneur is $\mathrm{P}-\mathrm{C}\left(\mathrm{Q}_{1}\right)+\mathrm{K}(\mathrm{E})$ - $\mathrm{E}$. In choosing the optimal effort level, he sets $K^{\prime}(E)=1$. Define $E_{f}$ as the effort level that satisfies this first order condition.

The not-for-profit firm faces a zero profit constraint, which means that total costs-- cash costs plus spending on perquisites -- must equal cash revenues. This zero profit constraint defines spending on perquisites: $\mathrm{Z}=\mathrm{P}-\mathrm{C}\left(\mathrm{Q}_{1}\right)+\mathrm{K}(\mathrm{E})$. In this case, the entrepreneur chooses the level of effort to maximize $d \bullet\left[P-C\left(Q_{1}\right)+K(E)\right]-E$, and first order condition is $d \cdot K^{\prime}(E)=1$. We let $E_{n}$ denote the level of effort that solves this equation. Comparing $\mathrm{E}_{\mathrm{n}}$ and $\mathrm{E}_{\mathrm{f}}$, and using the fact that $\mathrm{K}($.$) is concave,$ yields:

Proposition 1: Cost-reducing effort of the non-profit firm is lower than that of the for-profit firm. The consequent reductions in quality are therefore smaller in non-profits ${ }^{8}$.

When consumers contract for observable quality $\mathrm{Q}_{1}$, they agree to pay an initial price $\mathrm{P}$, which (as mentioned earlier) equals $\mathrm{q}+\mathrm{Q}_{1^{-}}-\mathrm{mE}$. The non-verifiable component of quality is correctly anticipated by consumers to be lower among for-profit firms. Holding verifiable quality constant, the price initially charged by non-profit entrepreneurs is therefore higher ${ }^{9}$.

\footnotetext{
${ }^{8}$ All the proofs are contained in the Appendix.
}

${ }^{9}$ Our basic model is set up in terms of the choice of quality and price by a selfish entrepreneur facing consumers. Some entrepreneurs might choose to have lower prices because they are altruists, 
The choice of contractual quality for either for-profit or non-profit firms maximizes $\mathrm{Q}_{1}$ $\mathrm{C}\left(\mathrm{Q}_{1}\right)$; this choice yields the first order condition: $1=\mathrm{C}^{\prime}\left(\mathrm{Q}_{1}\right)$. Contractible quality does not change with for-profit status and is denoted $Q_{1}^{*}$.. and we assume that $Q_{1}^{*}>\mathrm{C}\left(Q_{1}^{*}\right)$. The marginal value of contractible quality to the consumer equals to the marginal social cost of producing that quality. Thus non-contractible quality is higher in non-profit firms, but contractible quality is the same.

The non-profit status serves as a valuable commitment to higher quality only if the entrepreneur cannot pocket the profits by converting the firm to a for-profit status after collecting the revenues. Such conversions do occur in the United States, particularly in the hospital industry, but they restrict the use of profits by the for-profit firm. If effective, this device eliminates incentive to convert in order to distribute the profits, although some abuses do occur. As the law stands, then, non-profit status is a pretty credible commitment to non-collection of profits by the entrepreneur.

What legal status does the entrepreneur choose? The entrepreneur chooses not-for-profit status if:

$$
\mathrm{d} \bullet\left[\mathrm{q}+Q_{1}^{*}-\mathrm{mE}_{\mathrm{n}}-\mathrm{C}\left(Q_{1}^{*}\right)+\mathrm{K}\left(\mathrm{E}_{\mathrm{n}}\right)\right]-\mathrm{E}_{\mathrm{n}}>\mathrm{q}+Q_{1}^{*}-\mathrm{mE}_{\mathrm{f}} \mathrm{C}\left(Q_{1}^{*}\right)+\mathrm{K}\left(\mathrm{E}_{\mathrm{f}}\right)-\mathrm{E}_{\mathrm{f}},
$$

or equivalently

$$
\left(-\mathrm{mE}_{\mathrm{n}}+\mathrm{K}\left(\mathrm{E}_{\mathrm{n}}\right)-\mathrm{E}_{\mathrm{n}}\right)-\left(-\mathrm{mE}_{\mathrm{f}}+\mathrm{K}\left(\mathrm{E}_{\mathrm{f}}\right)-\mathrm{E}_{\mathrm{f}}\right)>(1-\mathrm{d}) \bullet\left[\mathrm{q}+Q_{1}^{*}-\mathrm{mE}_{\mathrm{n}}-\mathrm{C}\left(Q_{1}^{*}\right)+\mathrm{K}\left(\mathrm{E}_{\mathrm{n}}\right)\right]
$$

The left hand side of inequality (3) represents the benefits that a for-profit firm would obtain by committing to the non-profit firm's lower level of non-verifiable cost-reducing effort. The right hand side represents the loss imposed on a non-profit firm by the necessity to enjoy profits only as perquisites. This comparison represents the fundamental tradeoff between non-profit and for-profit

or because they want to attract donations from donors who are altruists. In this case, non-profit firms would receive donations and ration their products, rather than charge higher prices. 
status. The following proposition describes conditions determining the entrepreneur's choice of status:

Proposition 2: There exists a unique cutoff level of consumer taste for non-contractible quality, denoted $\mathrm{m}^{*}$, below which all entrepreneurs choose the for-profit status and above which they all select the non-profit status.

This proposition illustrates the crucial point that markets for goods where consumers do not value non-contractible quality would be dominated by for-profit firms, but markets where consumers do value such quality -- by the non-profits. When consumers care deeply about non-verifiable quality, entrepreneurs prefer non-profit status because it allows commitment to soft incentives and brings higher prices ex ante. The more valuable such quality, the more valuable is the ability to commit.

The next proposition derives further conditions on what makes an industry more likely to be dominated by non-profit firms.

\section{Proposition 3:}

(a) As the profitability of the entrepreneur or of the industry rises, the non-profit status becomes less desirable. More precisely, suppose $\mathrm{K}(\mathrm{E})=\mathrm{k}+\hat{K}(\mathrm{E})$ an $\mathrm{C}\left(\mathrm{Q}_{1}\right)=\mathrm{c}+\hat{C}\left(\mathrm{Q}_{1}\right)$. Then, as $\mathrm{q}$ or $\mathrm{k}$ rises or as $\mathrm{c}$ falls, $\mathrm{m}^{*}$ rises.

(b) If $\mathrm{d}$ is sufficiently low, then the for-profit status dominates the non-profit status.

According to part (a), when net revenues are high, entrepreneurs prefer for-profit status because spending these revenues on perquisites is too unattractive. With heterogeneity in 
costs among producers, the lower cost ones choose for-profit and the higher cost the non-profit status.

One implication of parts (a) and (b) together is that a very profitable firm, for which the marginal benefit of perquisites to an entrepreneur is trivial, is unlikely to be a non-profit.

The critical theoretical assumptions of our model are that ex post expropriation (1) hurts the purchaser (or employee or donor), (2) yields financial returns, and (3) has non-financial costs such as effort. Since non-profit status reduces the financial returns, but does not affect the non-financial costs, it softens incentives and entails less ex post expropriation in any setting that has these three features.

\section{Market Equilibrium}

When consumer tastes and the producer technology are homogeneous, inequality (3) either holds or fails for all possible entrepreneurs. As a consequence, all firms in an industry choose the same status. Indeed for profit firms almost completely dominate some industries (automobile manufacture), while non-profits dominate others (child care). On the other hand, in some industries, such as healthcare and theatres, for-profit and non-profit firms coexist. One possible reason for such coexistence is heterogeneity of consumer tastes. Assume, as an illustration, that (3) holds for most consumers and most firms choose non-profit status. If a small fraction of consumers receive no utility from non-contractible product quality, then for-profit firms would enter and supply just these consumers. Two types of firms then coexist in equilibrium: for-profits and non-profits, with the latter catering to consumers who demand high quality.

Co-existence of the two types of firms in equilibrium can also arise because of heterogeneity of employment relationships. For example, repertory theaters might need the non-profit status to 
commit to good treatment of actors who make large investments in their jobs, whereas more conventinal theatres do not rely on such investments, and hence can be for-profit. Hospitals to a significant extent cater to the interests of the doctors who treat patients there (Pauly and Ledish 1973, Herzlinger and Krasker 1987). If hospitals are organized as for-profit institutions, doctors may be concerned that the profits would be expropriated by the owners, whereas the non-profit status may serve as a commitment to spend the profits on wages and perquisities for doctors, including research. This argument would suggest that doctors who care the most about perquisites would gravitate toward non-profit hospitals. This argument would also suggest that, as profitability and hence the perquisite potential of hospitals declines, the attractiveness of the non-profit status declines as well. Consistent with this view, a significant number of non-profit hospitals have recently converted to a for-profit status under revenue pressure from managed care providers (Cutler and Horwitz 1997). The more general message here is that the analysis of the quality of hospitals for the doctors may be as important as that for the patients.

Even when markets are divided between for-profit and non-profit firms, it will be difficult to distinguish empirically between the quality of their output. The reason is that both types of firms would produce output of the same contractible quality, but non-profit firms would choose higher noncontractible quality. To the extent that non-contractible quality is hard to put in a contract and verify in court, it may also be difficult for an econometrician to measure. This may explain why some comparative studies of quality across for-profit and non-profit firms such as hospitals had trouble identifying any differences in observable quality (Norton and Staiger 1984) ${ }^{10}$.

One potentially interesting dimension of heterogeneity among consumers is the difference in

\footnotetext{
${ }^{10} \mathrm{~A}$ further problem is that these studies focus on quality from the perspective of patients, whereas the relevant perspective might be that of the doctors.
} 
the ability to monitor suppliers. Consumers who are bad at monitoring would then select non-profit firms to deal with. If governments are particularly weak at monitoring contracts (because of their own well known incentive problems), they will specialize in dealing with non-profit firms.

\section{Examples and Discussion}

Not for profit status is not the only means of softening incentives. Other institutional arrangements may supplement (or replace) it. For example, entrepreneurs with a particularly low known taste for perquisites, or whose consumption of perquisites can be restricted by a higher authority, might make particularly effective operators of non-profit firms. This may be the reason why so many non-profits such as schools and hospitals are operated by or affiliated with particular religions that restrict consumption.

Another device that serves the same purpose is a governing board consisting of people who are unable to consume perquisites, uninterested in the consumption of perquisites, or, perhaps ideally, are donors to the institution and therefore have an interest in restricting the consumption of perquisites. In fact, not-for-profit institutions typically have such governing boards. The benefits of the not-for-profit status for quality, then, can be amplified through additional devices reducing the value of perquisites to the decision makers.

Two further mechanisms that can help guarantee quality in either for- or not-for-profit firms are reputations and ex post competition. If a firm can establish a reputation for producing high quality and not engaging in cost and quality reducing innovations, it may be able to attract consumers at high prices regardless of its status. American universities, for example, try hard to maintain reputations for quality, as do the for-profit luxury car-makers.

Competition may further the same goal as well. Consider the ex post appropriation problem 
that results from worker investment in specific human capital (as in Rotemberg and Saloner, 1990). A firm can protect the worker by locating in an area where a large number of other employers also demand this particular form of human capital. When competition reduces risks of ex post appropriation, competition among for-profit firms may again render non-profit status unnecessary. Silicon Valley is a good example of this phenomenon. In the absence of such competition, however, the non-profit status becomes all the more essential. For example, universities in the US have traditionally served local markets (Hoxby, 1997) and only one university of a particular quality level often still serves a given metropolitan area. There is then little local competition for the services of professors who invest heavily in university-specific human capital. If universities were able to expropriate the rents from such investments, professors would refuse to invest. Non-profit status protects professors against this problem.

These examples raise the obvious question: what are the markets in which reputation and/or competition suffice for quality assurance by for-profit firms, and what are the markets where the notfor-profit status is necessary? Non-profit status is usually only necessary when the potential expropriation problem -- and the disutility to consumers or donors from reduced quality -- are very large. In the case of donations in particular, where the donor cannot take the money back or switch, the non-profit status might be essential. This logic might explain why we see non-profit hospitals (they deal with life and death and rely on donations) but not non-profit doctors (it is easier to switch or get a second opinion, and there are no donations). This logic might also explain why universities are non-profit (rely on donations) while vocational schools are not (no donations). Finally, this logic might explain why, for most goods where quality matters, market mechanisms are good enough for assuring quality production by for-profit firms. 


\section{A Taste for Quality}

Not-for-profit entrepreneurs often care about the quality of the good they are producing and not just the cash or perquisite returns. Indeed, many entrepreneurs who start non-profits appear to be do-gooders and idealists who genuinely care about their altruistic causes (Rose-Ackerman 1996). At the same time, Bill Gates appears to care deeply about making computing easy for everyone, yet Microsoft is a for-profit firm, so having a mission is not in itself the whole story. In this section, we describe some issues arising from entrepreneurial taste for quality.

We begin by assuming that entrepreneurs' taste for producing a quality product is observable and ask whether entrepreneurs with a greater taste for quality are more likely to choose non-profit status. We assume that the utility of an entrepreneur is:

$$
\text { Income }+\mathrm{d} \bullet \text { Perquisites }+\mathrm{a} \bullet \text { Quality }- \text { Effort }=\mathrm{I}+\mathrm{dZ}+\mathrm{a}\left(\mathrm{Q}_{1}-\mathrm{mE}\right)-\mathrm{E} \text {. }
$$

Otherwise, the model is exactly the same as that in the previous section ${ }^{11}$. In choosing the optimal effort level, the for-profit entrepreneur sets $K^{\prime}\left(E_{f}\right)=1+a m$. The non-profit entrepreneur chooses $\mathrm{d} \cdot \mathrm{K}^{\prime}\left(\mathrm{E}_{\mathrm{n}}\right)=1+\mathrm{am}$. Proposition 1 continues to hold and $\mathrm{E}_{\mathrm{f}}>\mathrm{E}_{\mathrm{n}}$.

For the purposes of this section, we assume that contractible quality $\mathrm{Q}_{1}$ is fixed. The new condition for an entrepreneur to choose the non-profit status is:

$$
(a+d)\left[Q_{1}-m E_{n}\right]-d\left[C\left(Q_{1}\right)-K\left(E_{n}\right)\right]-E_{n}>(a+1)\left[Q_{1}-m E_{f}\right]-C\left(Q_{1}\right)+K\left(E_{f}\right)-E_{f} .
$$

Since $\mathrm{E}_{\mathrm{f}}>\mathrm{E}_{\mathrm{n}}$, we have:

Proposition 4: Assume mK"'(E) $\leq[\mathrm{K} "(\mathrm{E})]^{2}$. Then increases in altruism (parameter a) make it more

${ }^{11}$ Once we allow entrepreneurs to care about quality, we can write down a simpler model in which an entrepreneur just chooses the quality level (no effort is spent on cost reduction). In such a model, commitment to the not-for-profit status would lead to higher quality levels because perquisites are not as valuable as income. We stick with a more complex model to show that a commitment to the not-for-profit status can benefit even a completely non-altruistic entrepreneur. 
likely that entrepreneurs prefer the non-profit status (i.e. inequality (4) holds). If there is a distribution of degrees of altruism, then the more altruistic entrepreneurs choose the non-profit status and the less altruistic ones choose the for-profit status.

According to this proposition, non-profit firms produce higher quality products, as qualityaltruists actually prefer. This, however, is not true in all cases, because there is a countervailing effect. Entrepreneurs with a greater taste for quality, which is known to all, may be able to earn greater revenues, which makes the for-profit status more appealing. The technical assumption rules out the possibility that very high altruism individuals find it unnecessary to use non-profit status to commit to high quality. Presumably, Mother Theresa could assure everyone of her commitment to quality of care for the indigent even if she ran a for-profit firm.

In many situations, consumers do not directly observe the producers' commitment to quality. Non-profit status may then signal that the entrepreneur cares more about quality relative to pecuniary rewards. Examples of this inference exist both in the health and the schooling industries, where consumers may be suspicious of for-profit firms because such firms may be more willing to cut services to raise profits. While we do not present a model in which non-profit status serves as a signal of altruism, such a model is straightforward to construct (the single-crossing property holds here). This point suggests that non-profit status is even more important in situations where individuals' altruism is not readily recognized.

When non-profit status attracts more altruistic producers, prices in non-profit firms need not always be higher than prices in for-profit firms, despite the fact that non-profits have higher unverifiable quality. If altruists care about offering low prices, which many at least claim to, then the altruistic producers in the non-profit sectors may set prices below those in the for-profit sector. Of 
course, there would then be queues in the non-profit sector. Thus Harvard and other top universities ration the slots in their entering classes, as do some of the non-profit long term care facilities. An alternative view is that low prices make administration easier, since there is less need for advertising and management (since there is always a queue of customers) and that non-profits set lower prices to avoid effort.

In summary, this section has made two points. In general, non-profit firms produce higher levels of quality and therefore attract entrepreneurs who care about quality more. Non-profit status may also convey information about the underlying commitment of the entrepreneur to quality provision. As such, non-profit status is a signal of a taste for quality.

\section{Donors}

In many situations, nonprofit firms provide charitable services for which they charge below cost, if anything. As a consequence, not-for-profit firms often rely on outside donations for part of their revenues ${ }^{12}$. Many individuals, with the help of the tax exemption for charitable donations, are willing to donate funds. Many donations can be understood as attempts to fund a particular project or interest of the donor or to gain social standing through displays of wealth and altruism. Such donors are best thought of as customers of the non-profit, and thus fit nicely into the model described above. The non-profit is supplying the donor with prestige or a very particular service (e.g., a full time researcher at a distinguished university dedicated to Gender Studies). The firm has the opportunity to either comply with the wishes of the donor (glorify her name or fulfill the implicit agreement) or to renege and simply use the money for other purposes. While any institution has its

\footnotetext{
${ }^{12}$ Weisbrod (1998) reports that private contributions as percentage of all nonprofit operating expenditures in the United States were $53.5 \%$ in 1964 , falling steadily to $23.6 \%$ in 1993 .
} 
reputation at stake in such a situation, a non-profit has less of an incentive to completely renege because of the limits placed on its use of new funds (Rose-Ackerman 1996). Non-profits have an advantage with donors, not only because of their tax status, but also because the inability to personally profit makes the people who run them more trustworthy.

A large number of donations are general funds given to an institution, not funds given for a particular purpose. In fact, donations sometimes lose their tax advantages when an explicit contract describing the terms of the arrangement is written. Moreover, in many non-profit institutions, funds are substantially fungible, and even specifically targeted gifts can be used for general purposes. To understand the role of general gifts to a non-profit institution, we must return to the previous model and explicitly incorporate an altruistic donor. Furthermore, we now assume that $\mathrm{V}(\mathrm{Z})$ is not linear, but an increasing, strictly concave function.

The timing of the model must be adjusted to include a donor. In period zero, the entrepreneur decides on the not-for-profit or the for-profit status. In period one, a donor decides on a level of general donations, denoted by $\mathrm{D}$. The donor correctly anticipates the effect of his donation on the future price and the non-contractible quality level. In period two, the entrepreneur sells the good to the consumer at a price $\mathrm{P}$ and a contractible quality level $\mathrm{Q}_{1}$. As in the previous section, we assume that there is only one possible level of contractible quality. In period three, the entrepreneur chooses his effort level E, which in turn determines non-contractible quality.

We assume that a donor who wishes to improve $\mathrm{Q}$, the overall quality of services provided by the firm, can only do so through general donations and cannot in any sense contract to directly induce the firm to deliver a higher quality product. The donor chooses the level of general donations, denoted by $\mathrm{D}$, to maximize (1-t)(I-D)+F(Q), where $\mathrm{I}$ is the donor's taxable income, $\mathrm{t}$ is the tax rate and $F(Q)$ is an increasing, twice differentiable concave function. The function $F(Q)$ is meant to 
capture the idea that the donor just wants to see good health, good universities or good theater. We assume that there is no competition, so a single entrepreneur is maximizing the utility function specified previously. If there is an interior solution for $\mathrm{D}$, the donor sets its level so that $\mathrm{dQ} / \mathrm{dD} \cdot \mathrm{F}^{\prime}(\mathrm{Q})=1-\mathrm{t}$. To ensure that this first order condition is a maximum, we assume that second order conditions hold.

In a for-profit firm, effort is set so that $1=\mathrm{K}^{\prime}(\mathrm{E})$. Increases in income do not change this first order condition, and donations have no effect on quality. This conclusion is too strong if the entrepreneur has diminishing marginal utility of income because of satiation. However, satiation with consumption as a whole is likely to set in much slower than satiation with perquisites, and hence for the comparison of non-profit and for-profit firms, we can assume constant marginal utility of income.

In a non-profit firm, in contrast, donations influence the marginal utility of perquisites and thereby affect quality. To solve the model, we proceed recursively and first solve for effort. The first order condition for effort is $\mathrm{K}^{\prime}(\mathrm{E}) \bullet \mathrm{V}^{\prime}(\mathrm{Y})=1$, where we use $\mathrm{Y}$ to denote net income: $\mathrm{Y}=$ $\mathrm{P}+\mathrm{D}+\mathrm{K}(\mathrm{E})-\mathrm{C}\left(\mathrm{Q}_{1}\right)$. We can then use the equilibrium relationship $\mathrm{P}=\mathrm{Q}_{1}-\mathrm{mE}$ to find the relationship between $\mathrm{E}$ and $\mathrm{D}$ that incorporates the idea that donations affect the price. We assume that $\mathrm{K}^{\prime}(\mathrm{E})+\left[\mathrm{V}^{\prime}(\mathrm{Y}) \bullet \mathrm{K}^{\prime \prime}(\mathrm{E})\right] /\left[\mathrm{V}^{\prime \prime}(\mathrm{Y}) \bullet \mathrm{K}^{\prime}(\mathrm{E})\right]>\mathrm{m}$ holds everywhere, which means that an increase in effort does not depress prices and profits so much that the marginal benefit from more effort itself increases. This condition must hold locally for the equilibrium to be stable. This condition ensures a unique equilibrium and that $\mathrm{dE} / \mathrm{dD}<0$-- donations reduce effort and increase quality. We then have:

Proposition 5: Donations (a) rise as the tax rate increases and (b) fall one-for-one as the firm obtains more alternative sources of income or as the price of the good increases. 
Part (a) suggests that tax deductible donations will be higher among donors who face a higher marginal tax rate. More importantly, part (b) implies that, as the firm acquires alternative sources of revenue, donations dry up. When firms are already rich, donors expect their donations to have less of a marginal impact on quality-related incentives and contribute less. Segal and Weisbrod (1998) find some evidence that donations and sales revenues are indeed substitutes for non-profit firms.

This result may explain why state-supported institutions receive few donations. State funding reduces private donations because private donors do not expect to have much of an impact on quality. ${ }^{13}$ In practice, there does appear to be a strong substitution between private charity and state funding. City Year, the national service organization founded by Brown and Khazei (discussed in the introduction), originally faced tremendous difficulties finding private donors to fund its programs, evidently because it already received sizable public funds. State universities in the United States have traditionally been less successful in fundraising than private schools. Indeed, both Yale and Harvard received most of their funding from state governments until the first quarter of the 19th century. The two schools only focused on private donations after the states cut them off for refusing to cater to the prevailing religious winds (Hansmann 1990). More recently, some state universities, in California, also turned to private donors after state funding became scarcer. In European countries, which have a long tradition of government funding of artistic, educational and medical institutions, there is much less of a tradition of private giving to such firms (until government funds dry up, as they did for British universities in the 1980s and Finnish musical institutions in the 1990s). Since the government has already created soft incentives for state-supported firms, private donors are not needed to further soften their incentives. funding.

${ }^{13}$ In addition, donors may fear the ratchet effect whereby their gifts reduce future state 
Proposition 5 also suggests that institutions will put themselves into situations where donations have a real effect on their incentives. For example, they may overcommit their resources so as to become cash poor. Or, like Harvard, they may restrict the discretion in using their resources as much as possible and attempt to appear unable to finance worthwhile new ventures without new donations. This implication explains why some institutions with extremely lush endowments still work hard to stay poor on the cash flow basis.

\section{Conclusion}

Not-for-profit firms are often controlled by entrepreneurs, and not by their employees or customers. The decision of entrepreneurs to establish such firms can be understood as an attempt to commit themselves to softer incentives. Soft incentives protect customers, volunteers, donors and employees of the firm against ex post expropriation. Donors in particular would favor non-profits with unrestricted donations even if such donations had no tax advantages because the risk of diversion of funds is much smaller. While sufficient reputation or competition may substitute for the non-profit status, in many cases we still expect entrepreneurs to seek the non-profit status, even if they are completely self-interested.

This basic framework yields several empirical predictions about non-profit firms. To begin, according to the theory, we expect to find non-profit firms in activities where:

1) there exist substantial opportunities for reductions of the quality of the good after it is purchased, or for other forms of expropriation of consumers;

2) the activity is not too profitable, or -- more importantly -- relies on charitable donations;

3) altruism or public spiritedness are important motivators of entrepreneurs;

4) it is costly for consumers or employees to change firms they deal with. 
The need for donations to assure the survival of a business is probably the most important determinant of the preference for non-profit status, because it is difficult to imagine a market mechanism that would support donations to for-profit firms.

Furthermore, in the activities where for-profit and non-profit firms coexist, we expect the latter to deliver higher quality to consumers. At the same time, we expect it to be difficult to detect such higher quality empirically, because easy to detect quality differences should be equalized through contracts. Finally, we expect to find higher levels of perquisites in non-profit firms, which may show up as better working conditions, wages, and benefits for the employees. Many of these implications appear to be consistent with the available evidence, while others are at least potentially testable. 


\section{References}

Arrow, Kenneth (1963), "Uncertainty and the Welfare Economics of Medical Care," American Economic Review 53: 941-973.

Ayala, J. and Falstad (1988) "American Repertory Theatre: 1988" Harvard Business School Case Study 9-688-120.

Cutler, David and Jill Horwitz (1997), “Converting Hospitals from Nonprofit to For profit Status: Why and What Effects?," Harvard University Mimeo.

Duggan, Mark (1998), “Effects of Ownership Structure on Hospital Behavior.” Mimeo, Harvard University.

Drucker, Peter (1990), Managing the Non-profit Organization: Practices and Principles, New York, NY: Harper Collins.

Easley, David and Maureen O'Hara (1983), "The Economic Role of the Nonprofit Firm," Rand Journal of Economics 14: 531-538.

Grossman, Sanford J. and Oliver D. Hart (1986), "The Costs and Benefits of Ownership: A Theory of Vertical and Lateral Integration," Journal of Political Economy 94: 691-719.

Grout, Paul (1984), “Investment and Wages in the Absence of Binding Contracts: a Nash Equilibrium Approach," Econometrica 52: 449-460.

Hansmann, Henry (1980), “The Role of the Nonprofit Enterprise,” Yale Law Journal 89: 835-901. Hansmann, Henry (1990), “Why do Universities Have Endowments?,' Journal of Legal Studies 19: $3-42$.

Hansmann, Henry (1996), The Ownership of Enterprise, Cambridge, MA: Harvard University Press. Hart, Oliver, (1995), Firms, Contracts, and Financial Structure (Oxford: Oxford University Press. 
Hart, Oliver and John Moore (1997), "Cooperatives vs. Outside Ownership,” Harvard University Mimeo.

Hart, Oliver, Andrei Shleifer, and Robert Vishny (1997), “The Proper Scope of Government: Theory and an Application to Prisons." Quarterly Journal of Economics 112: 1127-1162.

Herzlinger, Regina and William Krasker (1987), "Who Profits from Nonprofits?" Harvard Business Review January-February: 93-106.

Holmstrom, Bengt, and Paul Milgrom, (1991),"Multi-task Principal-Agent Analyses: Incentive Contracts, Asset Ownership and Job Design," Journal of Law, Economics and Organization 7: $24-52$.

Holmstrom, Bengt, and Paul Milgrom,(1994), "The Firm as an Incentive System," American Economic Review 84: 972-91.

Hoxby, Caroline (1997), "How the Market Structure of U.S. Higher Education explains College Tuition," Mimeo, Harvard University

Klein, Benjamin, Robert Crawford, and Armen Alchian, (1978), "Vertical Integration, Affordable Rents and the Competitive Contracting Process," Journal of Law and Economics, 21(2).

Kremer, Michael (1997) “Why are Worker Cooperatives So Rare?” Mimeo, MIT.

Lakdawalla, Darius and Tomas Philipson (1998), "Nonprofit Production, Competition, and Long-term Care," Mimeo, University of Chicago.

Nelson, Richard and Michael Krashinsky (1973), "Two Major Issues of Public Policy: Public Policy and the Organization of Supply," in Richard Nelson and Dennis Young, eds., Public Subsidy for Day Care of Young Children, Lexington, MA: D.C. Heath.

Pauly, Mark and Michael Redisch (1973), “The Not-for-profit Hospital as a Physicians' Cooperative," American Economic Review 63(1), 87-99. 
Rose-Ackerman, Susan (1996), "Altruism, Non-Profits, and Economic Theory," Journal of Economic Literature 34: 701-728.

Rotemberg, Julio and Garth Saloner (1990), "Competition and Human Capital Accumulation: A Theory of Interregional Specialization and Trade,” Mimeo, MIT.

Segal, Lewis and Burton Weisbrod (1998), "Interdependence of Commercial and Donative Revenues," Chapter 6 in Burton Weisbrod, ed. (1998), 105-127.

Shleifer, Andrei (1998), "State versus Private Ownership," Journal of Economic Perspectives, forthcoming.

Weisbrod, Burton (1988), The Nonprofit Economy, Cambridge, MA: Harvard University Press.

Weisbrod, Burton, ed. (1998), To Profit or Not to Profit. The Commercial Transformation of the Nonprofit Sector, Cambridge, U.K.: Cambridge University Press. 


\section{Appendix: Proofs of Propositions}

Note: Throughout this appendix we assume that $\mathrm{q}+Q_{1}^{*}-\mathrm{C}\left(Q_{1}^{*}\right)>0, \mathrm{~K}(0)>0$ and $\mathrm{K}^{\prime}(0)=\infty$. Furthermore, we denote $\mathrm{H}=\mathrm{q}+Q_{1}^{*}-\mathrm{C}\left(Q_{1}^{*}\right)$.

Proposition 1: The first order condition determining innovative effort for the non-profit firm is $\mathrm{dK}^{\prime}(\mathrm{E})=1$. Differentiating with respect to $\mathrm{d}$ yields $\partial \mathrm{E} / \partial \mathrm{d}=-1 / \mathrm{d}^{2} \mathrm{~K} "(\mathrm{E})>0$. Thus, the level of $E$ chosen when $d=1$, the case of a for-profit firm must be higher than the level of $E$ chosen when $d<1$ (the case of a non-profit firm). Ex-post reductions in quality rise linearly with $\mathrm{E}$ so the for-profit firm makes greater reductions in quality.

Proposition 2: If we define:

(A1) $\quad \mathrm{W}(\mathrm{m})=(1-\mathrm{d}) \mathrm{H}+\mathrm{K}\left(\mathrm{E}_{\mathrm{f}}\right)-(1+\mathrm{m}) \mathrm{E}_{\mathrm{f}}-\mathrm{dK}\left(\mathrm{E}_{\mathrm{n}}\right)+(1+\mathrm{dm}) \mathrm{En}=\mathrm{B}+\left(\mathrm{d} \mathrm{E} \mathrm{E}_{\mathrm{n}}-\mathrm{E}_{\mathrm{f}}\right) \mathrm{m}$

as the difference between entrepreneurial utility with for-profit status and with non-profit status. The term $B$ is a combination of terms that are independent of $m$. As the effort terms do not depend on $\mathrm{m}, \mathrm{W}^{\prime}(\mathrm{m})=\mathrm{dE}_{\mathrm{n}}-\mathrm{E}_{\mathrm{f}}<0$, so $\mathrm{W}(\mathrm{m})$ is linear, and for sufficiently large levels of $\mathrm{m}, \mathrm{W}(\mathrm{m})<0$. Furthermore $\left.\mathrm{W}(0)=(1-\mathrm{d}) H+K\left(E_{\mathrm{f}}\right)-E_{\mathrm{f}}-\mathrm{dK}\left(\mathrm{E}_{\mathrm{n}}\right)+\mathrm{E}_{\mathrm{n}}=(1-\mathrm{d}) \mathrm{H}+(1-\mathrm{d}) \mathrm{K}\left(\mathrm{E}_{\mathrm{n}}\right)+\left(\mathrm{K}\left(\mathrm{E}_{\mathrm{f}}\right)-\mathrm{E}_{\mathrm{f}}\right)-\left(\mathrm{K}\left(\mathrm{E}_{\mathrm{n}}\right)-\mathrm{E}_{\mathrm{n}}\right)\right)>0$. This in equality holds because 1>d, $H>0, K\left(E_{n}\right)>0$, as $E_{f}$ is chosen to maximize $K(E)-E$, it must be that $K\left(E_{f}\right)-E_{f}$ $\geq \mathrm{K}\left(\mathrm{E}_{\mathrm{n}}\right)-\mathrm{E}_{\mathrm{n}}$. As $\mathrm{W}(0)>0$ and $\mathrm{W}$, is continuous and monotonically decreasing and $\mathrm{W}(\mathrm{X})<0$ for some sufficiently large enough $\mathrm{X}$, there must exist an $\mathrm{m}^{*}$ such that $\mathrm{W}\left(\mathrm{m}^{*}\right)=0$ and non-profit status dominates for-profit status for all $\mathrm{m}>\mathrm{m}^{*}$ and for-profit status dominates non-profit status for all 
$m>m^{*}$. More precisely $m^{*}=B /\left(E_{f}-d E_{n}\right)>0$, and variables that increase or decrease $B$, without changing $E_{\mathrm{f}}-\mathrm{d} \mathrm{E}_{\mathrm{n}}$, also increase or decrease $\mathrm{m}^{*}$.

Proposition 3: Part (a): Changes in $\mathrm{q}, \mathrm{k}$ and $\mathrm{c}$ do not affect the choice of effort level or verifiable quality. Differentiation reveals $\partial \mathrm{B} / \partial \mathrm{q}>0, \partial \mathrm{B} / \partial \mathrm{k}>0$ and $\partial \mathrm{B} / \partial \mathrm{c}<0$ so $\partial \mathrm{m} * / \partial \mathrm{q}>0, \partial \mathrm{m} * / \partial \mathrm{k}>0$ and $\partial \mathrm{m} * / \partial \mathrm{c}<0$.

Part (b): At $d=0, W(m)$ equals the profits that would be made by the for profit firm, which are assumed to be positive, so for-profit status is strictly preferred. As W is continuous in d, for values of $\mathrm{d}$ close to zero $\mathrm{W}(\mathrm{m})$ will also be positive.

Proposition 4: Define the utility advantage of choosing for-profit status as:

(A1') $W(a)=(1-d) H+K\left(E_{f}\right)-(1+m+a m) E_{f}-d K\left(E_{n}\right)+(1+d m+a m) E_{n}$

Differentiation, and using the first order conditions that determine effort, reveals that $W^{\prime}(a)=m\left(E_{n^{-}}\right.$ $\left.E_{f}\right)+m^{2}\left(1 / K^{\prime \prime}\left(E_{n}\right)-1 / K^{\prime \prime}\left(E_{f}\right)\right.$ ). As long as $X+m / K^{\prime \prime}(X)$ is rising in $X$ (which requires that $\left.\mathrm{K}^{\prime \prime}(\mathrm{X})^{2}>\mathrm{mK} \mathrm{\prime}^{\prime \prime}(\mathrm{X})\right)$ then $\mathrm{W}^{\prime}(\mathrm{a})<0$ since $\mathrm{E}_{\mathrm{n}}>\mathrm{E}_{\mathrm{f}}$.

Proposition 5: Part (a) follows since the first order condition for the donor is that $F^{\prime}(Q) d Q / d D=1-t$. Differentiating this condition implies that $d D / d t=-1 /\left[F^{\prime \prime}(Q)(d Q / d D)^{2}+F^{\prime}(Q) d^{2} Q / d D^{2}\right]$. The denominator of this expression is negative because we assume that second order conditions hold. 
To prove part (b) of the proposition, we define a parameter y which reflects exogenous increases in the profits of the firm. In equilibrium, the price must equal $\mathrm{q}+\mathrm{Q}_{1}-\mathrm{mE}$, where $\mathrm{q}$ is a demand shift parameter. Total net income for the firm is therefore $D+K(E)-m E+y+q+Q_{1}-C\left(Q_{1}\right)$ which we again denote $Y$. Differentiating $K^{\prime}(E) V^{\prime}(Y)$ reveals that as long as $K^{\prime}(E)+\left[K^{\prime \prime}(E) V^{\prime}(Y)\right] /\left[K^{\prime}(E) V^{\prime \prime}(Y)\right]>m$ then there is a unique level of effort which satisfies the first order conditions for any given level of $\mathrm{D}+\mathrm{y}+\mathrm{q}$; we denote this level of effort as $\mathrm{E}(\mathrm{D}+\mathrm{y}+\mathrm{q})$. Using $\mathrm{K}^{\prime}(\mathrm{E})+\left[\mathrm{K}^{\prime \prime}(\mathrm{E}) \mathrm{V}^{\prime}(\mathrm{Y})\right] /\left[\mathrm{K}^{\prime}(\mathrm{E}) \mathrm{V}^{\prime \prime}(\mathrm{Y})\right]>\mathrm{m}$, it follows that $\mathrm{dE} / \mathrm{dD}=\mathrm{dE} / \mathrm{dy}=\mathrm{dE} / \mathrm{dq}<0$ (i.e. increases in demand, profits and donations have the same negative effect on cost-reducing effort). The first order condition for the donor can be rewritten as $F^{\prime}\left(Q_{1}-m E(D+y+q)\right) m E^{\prime}(D+y+q)=1-t$. Differentiation of this condition equals reveals that $\mathrm{dD} / \mathrm{dy}=\mathrm{dD} / \mathrm{dq}=-1$, which means that increases in the price or profits lead to one-for-one reductions in donations. 